YEARBOOK

of ANTITRUST

and REGULATORY

STUDIES

www.yars.wz.uw.edu.pl
Peer-reviewed scientific periodical, focusing on legal and economic issues of antitrust and regulation. Creative Commons Attribution-No Derivative Works 3.0 Poland License.

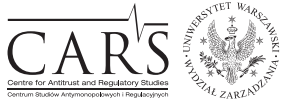

Centre for Antitrust and Regulatory Studies, University of Warsaw, Faculty of Management www.cars.wZ.uw.edu.pl

\title{
Substantive and Procedural Issues of Cement Sector Investigations in Turkey
}

\author{
by
}

Hanna Stakheyeva and Ertugrul Canbolat*

\section{CONTENTS}

I. Substantive and procedural issue of sector inquiries in Turkey

1. Introduction

2. Main findings under the Cement Sector Report

2.1. Cement as a local consumption product

2.2. No correlation between demand and demand structure: questioning market seasonality argument

2.3. No clear correlation between price and market concentration levels

2.4. No correlation between price and cost

2.5. Bulk v packaged cement: price similarities

3. Procedural issues of sector inquiries directed at cement manufacturers: right to request information $\mathrm{v}$ duty to provide information

3.1. Introduction

3.2. Legal grounds for information requests

3.3. Limitations to (scope of) information requests

II. Most common competition law violations in cement sector: major cases in Turkey

1. 1997-1999 investigations

2. 2003-2004 investigation

3. 2012-2014 investigation

* Hanna Stakheyeva, Assistant Professor, Bogazici University, Istanbul, Turkey, hanna. stakheyeva@actecon.com; Ertugrul Canbolat, LL.M., Competition law expert, Istanbul, Turkey, ertugrul.canbolat@actecon.com. Article received: 4.04.2017, accepted: 30.04.2017. 
4. 2014-2016 investigations

4.1. No violation found

4.2. Allegations confirmed

III. Conclusion

\section{Abstract}

In 2016, the Turkish Competition Authority (hereinafter, TCA) published the Cement Sector Inquiry Report (hereinafter, Cement Sector Report) following more than two years of market analysis. One of the reasons for conducting such a market inquiry was the fact that the implementation of competition rules and accuracy of the economic analysis by the TCA in cement cases were frequently criticized. In order to provide some guidance and have better understanding about the competitive dynamics of the cement market, the TCA initiated the inquiry in 2014. Another reason for the inquiry was the importance of the cement industry for the construction sector and the economy of Turkey, as well as numerous competition law concerns in this sector.

The article provides an analysis of the substantive and procedural issues in the TCA activity in the cement sector in Turkey. Particular emphasis is placed on the assessment of the Cement Sector Report and common competition law violations in the sector in Turkey based on a review of the decisions of the TCA. Additionally, legal grounds for conducting sector inquiries in Turkey, as well as limits to and potential impact on the TCA's powers to issue extensive compulsory information requests (in the light of the recent CJEU's judgements in cement cartel cases) are discussed. Overall, the article provides the reader with a better understanding of the Turkish cement sector dynamics and most common anticompetitive practices there. In conclusion, it is argued that inspite of having a reputation of a "problematic sector", the behaviour of cement producers and developments in the cement market in Turkey may be justified by economic reasons and the oligopolistic nature of this market.

\section{Resumé}

En 2016, l'Autorité turque de la concurrence (ci-après, ATC) a publié le rapport d'enquête sur le secteur du ciment (ci-après, Rapport sur le Secteur du Ciment) après plus de deux ans d'analyse du marché. Une des raisons pour mener une telle enquête de marché était le fait que la mise en œuvre des règles de concurrence et l'exactitude de l'analyse économique par l'ATC dans les affaires concernant le marché du ciment étaient fréquemment critiquées. Afin de fournir des conseils et une meilleure compréhension de la dynamique concurrentielle du marché du ciment, l'ATC a lancé l'enquête en 2014. Une autre raison de l'enquête était l'importance de l'industrie du ciment pour le secteur de la construction et l'économie turque, ainsi que de nombreuses préoccupations en matière de droit de la concurrence dans ce secteur. 
Larticle fournit une analyse des questions de fond et de procédure dans l'activité ATC dans le secteur du ciment en Turquie. Laccent particulier est mis sur l'évaluation du Rapport sur le Secteur du Ciment et des violations du droit de la concurrence communes dans le secteur en Turquie sur la base d'un examen des décisions de l'ATC. En outre, les motifs juridiques pour mener des enquêtes sectorielles en Turquie, ainsi que des limites et des effets potentiels sur les pouvoirs de la ATC d'envoyer des demandes d'informations vastes et obligatoires (à la lumière des arrêts récents de la CJUE dans les affaires de cartel de ciment) sont abordés. Dans l'ensemble, l'article permet au lecteur de mieux comprendre la dynamique du secteur du ciment en Turquie et les pratiques anticoncurrentielles les plus communes dans ce pays. En conclusion, il est soutenu que, malgré sa réputation d'un «secteur problématique», le comportement des producteurs de ciment et les développements sur le marché du ciment en Turquie peuvent être justifiés par des raisons économiques et le caractère oligopolistique de ce marché.

Key words: antiturst decisions; anticompetitive practice; cement; information requests; obligation to provide information; sector inquiry; Turkey; Turkish Competition Authority

JEL: K21

\section{Substantive and procedural issues of sector inquiries in Turkey}

\section{Introduction}

"[...] every system of competition law will deal with cartels and the first thing for any new competition regulator is to go out and find the cement cartel. [...] it is always there, somewhere [...]". This statement of R. Whish (2001) illustrates the reality of the competition authorities' approach to the cement market in various jurisdictions, including Turkey. It has become a prejudgement mostly because in sectors "where standardized products are produced and/or sold [...], the parameters to agree are generally issues about price and sale; therefore, cartels are more frequent" 1 . However, at the same time we should not forget that the cement sector is characterised by the oligopolistic structure, hence even if the undertakings compete with each other, it is not realistic to observe price trends that are expected from the

1 OECD Roundtable On Promotıng Compliance With Competition Law - Note by the Delegation of Turkey, Directorate For Financial And Enterprise Affairs Competition Committee, DAF/COMP/WD(2011)36, 2011, p. 16. Retrieved from: http://www.rekabet.gov. tr/File/?path=ROOT\%2f1\%2fImages\%2fHaber\%2f71_Compliance_Turkey.pdf (20.01.2017). 
fully competitive market structure. This situation is accepted in the economic theory.

Nevertheless, the cement sector has always attracted attention of the competition authorities worldwide. Back in 1994, the European Commission fined 42 companies for partitioning the cement market among themselves and various information exchanges (the fine was reduced by the Court of Justice from EUR 248 million to EUR 108 million). In 2003, Bundeskartellamt (German Competition Authority) fined 6 cement companies EUR 660 million for colluding and setting production quotas. In 2008-2009, the European Commisison conducted inspections of several leading cement companies on suspicion of forming a cartel${ }^{2}$ (although following the investigation it decided to close the case due to lack of evidence). In 2009, the Office of Competition and Consumer Protection of Poland imposed a fine of EUR 99 million on 7 cement producers ${ }^{3}$.

In Turkey, the cement sector has been under the supervision of the TCA since its establishment in $1997^{4}$. In fact, the first investigation of the TCA was on the cement market (Çelen and Gunalp, 2010, pp. 150-168). The cement sector is considered one of the most profitable and at the same time troublesome sectors in Turkey 5 . This explains the increased attention and competition enforcement efforts of the TCA in the form of investigations, fines, as well as sector inquiries. The latest cement sector inquiry was finalized in December 2016. Main substantive and procedural issues arising from the Report are analysed in the below sections.

\section{Main findings under the Cement Sector Report}

\subsection{Introductory remarks}

The TCA decided to initiate a sector inquiry and to conduct both descriptive and statistical analyses of the cement market in 2014, considering

2 Commission welcomes General Court judgments in cement cartel case confirming its investigatory powers- Press Realese, Brussels, 14.03.2014. Retrived from: http://europa.eu/rapid/ press-release_MEMO-14-192_en.htm (20.01.2017).

3 Commission opens antitrust proceedings against a number of cement manufacturers - Press Release, IP/10/1696, Brusssels, 10.12.2010. Retrieved from: http://europa.eu/rapid/pressrelease_IP-10-1696_en.htm?locale=en (20.01.2017).

4 The Turkish Competition Law was adopted in 1994, the Turkish Competition Authority was established in 1997, when the Turkish Competition Law started to be effective.

5 This is one of the reasons why the privatization in Turkey began with cement sector in 1989 (Demek, 1994, p. 18). Retrived from: http://seyhan.library.boun.edu.tr/record=b1154512 S5 (25.01.2017). 
the importance of the cement industry for the construction ${ }^{6}$ and economy of Turkey and numerous competition issues in this sector. Following two years of research and analysis of the cement market, the Cement Sector Report was published in the TCA's website 7 .

The Cement Sector Report includes economic analysis of several issues regarding the Turkish cement sector, such as demand-price, efficiency-price, and cost-price comparison, as well as market allocation and profit maximization in relation to possible anti-competitive indicators. The Cement Sector Report may be regarded as "guidelines" to the TCA's future approachregarding the cement market.

The overall focus of the Cement Sector Report is on the cement market structure and pricing policies. Considering that cement is a homogeneous product, customers choice between cement producers would depend primarily on price. The cement industry is notorious worldwide for certain anti-competitive practices and coordination. Cartels, as the most serious anti-competitive practice in the cement sector, are considered to be effective when on a limited scale, i.e. in a local or regional market that is dominated by a few cement plants. Due to the fact that cartels are costly to operate particularly on a large scale, there are other practices with the help of which the companies may potentially coordinate their behaviours, i.e. with the help of (1) basing point system where the market price is set by the leading company according to the base mill price, and other smaller competitiors become price-takers; (2) vertical integration by way of buying the concrete producing companies; (3) information exchanges, etc. (Dumez and Jeunemaître, 2000, p. 8).

Price increases in the cement sector are very common. According to the Cement Sector Report, price increases for cement in Turkey starting from 2013 have prominently been above the inflation rate. While this may raise certain competition law concerns, at the same time price increase alone cannot be considered as a per se violation of competition rules. A case-by-case examination is necessary to understand whether the pricing could be explained by economic reasons, such as cost, demand structure, growth, etc. Interestingly, the Cement Sector Report concludes that there is no direct correlation between price and either demand structure, or concentration in the cement market, or cost.

\footnotetext{
${ }^{6}$ Cement being one of the fundamental inputs in the construction sector.

7 Cement Sector Report, 2016. Retrieved from: http://www.rekabet.gov.tr/File/?path=R OOT $\% 2 \mathrm{f} 1 \% 2 \mathrm{fDocuments} \% 2 \mathrm{fG} \% \mathrm{C} 3 \% \mathrm{BCncel} \% 2 \mathrm{fraporlar} \% 2 \mathrm{f} \% \mathrm{C} 3 \% 87$ imento + Sekt $\% \mathrm{C} 3 \%$ $\mathrm{B} 6 \mathrm{r}+$ Raporu+-+Ticari+s\%C4\%B1rlardan+ar\%C4\%B1nd\%C4\%B1r\%C4\%B1lm\%C4\%B1\%C5\%9F.pdf (27.03.2017).
} 


\subsection{Cement as a local consumption product}

Cement tends to be a local consumption product due to high transportation cost (around $10-15 \%$ of the total value added, with trucks being the prevailing means of transportation (Dernek, 1998, 39). Hence, local producers have a considerable advantage in their local market (Dernek, 1998). The same views have been expressed by Dumez and Jeunemaitre (2000, p. 12):

"Each plant can be seen as at the centre of a "natural" market, the boundaries of which are determined by the relationship between production costs (which fall strongly as the size of plant and its rate of utilisation increase), and transportation costs (which rise with distance). A cement producer is secure from competition within his natural market as the price he will normally quote, given the combination of production and transportation costs, is lower than that which can be quoted by distant competitors".

It is clear that cement producers are normally selling within their geographical area, and they do not tend to change the boundaries of their own market even when the economic conditions change. In our opinion, this could be regarded as the natural business strategy of cement producers, which may be explained by the peculiarities of the cement sector (capital-intensive industry, regional market, high transportation cost, and local competition).

\subsection{No correlation between demand and demand structure: questioning market seasonality argument}

The TCA states that the cement market is characterised by the periodic/ seasonal demand structure, which normally decreases in September/October and increases in March/April ${ }^{8}$ reflecting the business cycle of the construction industry and country's climate. This issue has been addressed by the TCA in its previous decisions. For instance, in its Decision No 13-07/65-34 as of 24 January 2013, the TCA confirms that the following circumstances are frequently encountered in the cement sector: seasonal demand for cement, increase in prices associated with the escalating demand during spring-summer months, decrease in prices due to the fall in demand during winter months, and similarities in price movements of different cement producers.

At the same time, in spite of the seasonal structure, the TCA has also observed in its decisions that prices do not always correlate with the demand patterns. As a general trend, the price does not always decrease in the the low-demand periods. An increase in price would not also have an impact on demand for cement, since there is no substitute to it in a short run at least

\footnotetext{
8 TCA - Cement Sector Report, Section II.E.I, p. 28, para. 1.
} 
(Dumez and Jeunemaître, 2000). In other words, an increase in price takes place independently from the demand tendencies. For instance, the TCA in its Decision No 12-17/499-140 dated 6 April 2012 found that cement price movements were not related to the market structure and refused seasonality defenses of the parties concerned. Therefore, considering that there is no unquestionable relation between the cement prices and seasonal demand, in the TCA's opinion, any price increase defence strategies based on the seasonality of the cement market are unlikely to be accepted in the future without any other sufficient economic infrastructure and convincing information/evidence.

\subsection{No clear correlation between price and market concentration levels}

Another important finding of the Report in relation to prices is that no clear positive or negative correlation between price and concentration in the cement market has been observed by the $\mathrm{TCA}^{9}$. Prices are at a close level in both highly and less concentrated regional markets. The Report concluded that market shares of undertakings are rather low at the national level, but at the same time, certain undertakings have a greater market power in certain cities. The concentration levels differ depending on the city (and number of companies making sales there). The higher the number of undertakings, the more price differences in a city may be observed.

\subsection{No correlation between price and cost}

The TCA carried out its analyses regarding the relation between prices and costs in both short-term and long term perspective (by using various methods such as autoregressive distributed lag, cointegration and error correction models, Engle-Granger). In the end, no close correlation between cement price and cost was found by the TCA. Cement production is normally characterized by significant economies of scale, meaning that the average cost may be reduced by increasing output (Dernek, 1998). When output does increase, however, changes in costs are not really reflected in price movements. In other words, if the company manages to reduce its cost of cement production, the prices will not normally decrease relatively, according to the TCA's findings.

It has not been possible to determine a positive relation between costs and prices as expected in economics and theory. It has been observed that the concerned relation is mostly a negative one, meaning that in the event where the costs for the production of the cement decline, the prices do not always decrease, but rather, may increase.

\footnotetext{
9 TCA - Cement Secor Report, Section III.B.II.I, Table 29, p. 78.
} 


\subsection{Bulk $\mathrm{v}$ packaged cement: price similarities}

The Report also evaluates cement as a product and notes that bulk cement is sold more (min. $60 \%$ of cement sales per year ${ }^{10}$ ) than packaged cement ${ }^{11}$. Packaged cement is mostly sold through dealers, while bulk cement is mostly sold to the ready-mixed concrete facilities. In other words, concerning the bulk cement, dealers constitute a significant customer share (28\%) although the ready-mixed concrete plants represent the primary customer group. On the other hand, dealers lead in the field of packaged cement with an $87 \%$ share $^{12}$. The TCA has concluded that there is some degree of similarity between the price trends for certain types of bulk cement products, but still the price trends for various types of packaged cement are very close to each other.

This may be explained by the fact that the cement sector demonstrates the characteristics of an oligopolistic market structure. Even if the undertakings compete with each other, it is not realistic to observe price trends that are expected from the fully competitive market structure. This situation is accepted in the economic theory. On the other hand, in cases where prices are determined through an agreement or concerted practices (by the competing undertakings), the price level will be higher than the level arising from the oligopolistic competition. The competition law, particularly in Article 4 of the Turkish Competition Law (hereinafter, TCL), prohibits this. That said, the determination of prices by the competing undertakings (without existence of any agreements or concerted practices) below the competitive levels just because of oligopolistic interdependence and rational choices is known and accepted in both theory and commercial life. This shall not be considered as a violation from the perpective of competition law.

The Report provides data on 404 simulations made in the course of 5 years (2010-2014) and in 81 provinces in relation to calculation of prices, which arise in cases where the production and sales units show oligopolistic competition (Bertrand game) and profit maximisation behaviours (either wholly or partially together $)^{13}$. In the light of the findings, the Report states that the common

10 This is valid for the cement products under codes 14 and 24.

11 TCA - Cement Sector Report, Section III.B.II.III, p. 102.

12 TCA - Cement Sector Report, Section III.B.II.IV, p. 103-104, Chart 34 and 35.

13 In terms of the observations made for the cases where only one unit operates currently, the monopolistic course of behaviour has been included into the simulations. The prices obtained as a result of the simulations and actually observed average prices in the concerned province/ year have been compared and the closest course of behaviours/actions to the reality has been established. Considering the simulation performances of the closest scenarios to the reality and the proximity ratios between calculated and real prices, it has been evaluated in three categories (5\% or below, between $5 \%$ and $10 \%$, and between $10 \%$ and $15 \%$ ). Accordingly, in 277 observation points from 404, the difference between the calculated prices for the closest 
course of behaviour in the cement sector is the "joint profit maximisation"14, in terms of the provinces and years. Therefore, it is possible to argue that the observed price levels in the cement sector during recent years generally (except some observation points) were determined above the levels that are expected from oligopolistic competition in terms of the economic analysis. On the other hand, it does not necessarily confirm the existence of anticompetitive practices between the undertakings; rather it may be a result of rational choices of the cement companies in the circumstances of an oligopolistic market.

The Report emphasizes that the cement market is rather difficult for the new players to enter due to certain economic and legal entry barriers. The TCA concluded that the cement sector in Turkey bears anti-competitive characteristics. The product and market structure of the cement sector facilitate the implementation of anticompetitive practice and collusion. The TCA has not taken any action as a result of the Report yet. However, it may be anticipated that the economic activities of the cement companies in Turkey will continue to be under a special scrutiny of the TCA in order to improve competition.

\section{Procedural issues of sector inquiries directed at cement manufacturers: right to request information versus duty to provide information}

\subsection{Introduction}

Both antitrust investiations and sector inquiries aim at increasing competition in the market. At the same time, both may result in the cement market becoming more transparent and paradoxically more suitable for collusion. As noted by Çelen and Gunalp (2010, p. 166), "most of the studies that have addressed this question have reached the startling conclusion that antitrust enforcement does not lead to lower prices". "Indeed, antitrust investigations do not lead to the decrease in prices, but rather serve as a preventive mechanism for future violations - as a disincentive, discouraging factor for the companies to collude considering the level fines". In fact, the findings of Çelen and Gunalp's research emphasize that the investigations conducted by the TCA have made the cement market more competitive.

scenarios to the reality and observed prices is $15 \%$ or below. In 234 of these 277 observations, the joint profit maximisation behaviour reveals a result with $15 \%$ or much lower proximity in average. Taking lower proximity levels into account, it is seen that the wholly or partially joint pricing behaviour in cement sector generates results to the observed prices in reality at a significant rate.

14 TCA - Cement Sector Report, Section III.D, p. 131. 
While we share this opinion, it should be also stated that there are certain issues which require clarifications and improvements such as the duration of the investigation procedure (which is rather long - normally the TCA takes the decision within 2 years), powers of the TCA to request extensive information/ documents from the parties, and the appeal procedure to the court of first instance/the Council of State. Let us focus of the issue of TCA's powers to request information (which could also be used as one of the procedural grounds for appeal of the decision) and its comparative analysis with those that the European Commission enjoys.

Request for information shall be regarded as a (preliminary) investigative measure, part of the investigation procedure/sector inquiry enabling the competition authorities to obtain information/documentation and verify the actual existence and scope of a specific factual and legal situation in the market ${ }^{15}$.

\subsection{Legal grounds for information requests}

The TCA uses its investigatory powers through request for information and on-the-spot inspections ${ }^{16}$. The TCA under Article 14 TCL may request any information it deems nesessary from all public/private institutions and organizations, undertakings and associations of undertakings; while officials of these authorities, undertakings and associations of undertakings are obliged to provide the requested information within the period determined by the TCA ${ }^{17}$.

In the EU, under Regulation 1/2003, there are two obligations for both the authority and the undertakings concerned: obligation to state reasons: the European Commission, in requesting information via its formal decision, must specify legal basis and purpose of such request, as well as fix the time limit for the companies to respond to the request ${ }^{18}$ and obligation to provide the requested information ${ }^{19}$.

15 ECJ judgment of 18.10.1989, Case C-374/87 Orkem v Commission, ECLI:EU:C:1989:387, para. 21.

16 Besides the requests for information, in order to gather information/documents for the purposes of investigation, the TCA may conduct on-the-spot inspections. Within this scope, the TCA may perform examinations/searches at the premises of undertakings and associations of undertakings where it deems necessary. Legal basis authorizing the TCA in terms of on-the-spot inspections is Article 15 of the Turkish Competition Law. In cases where undertakings do not cooperate with the TCA, it is highly likely that administrative fines would be inevitable for them.

$17 \mathrm{http} / /$ www.rekabet.gov.tr/en-US/Pages/Act-No-4054 (25.01.2017).

18 Article 18(3) of Regulation 1/2003. It shall also indicate the penalties provided for in Article 23 and indicate or impose the penalties provided for in Article 24. It shall further indicate the right to have the decision reviewed by the Court of Justice.

19 In addition, recital 23 in the preamble to Regulation 1/2003 states: "The Commission should be empowered throughout the Community to require such information to be supplied as is necessary to detect any agreement, decision or concerted practice prohibited by [Article 
The European Commission may request information when when a relationship between the information and alleged behaviours exists ${ }^{20}$, while companies are required to provide all information requested by the Commission $^{21}$. In case of ignoring formal requests for information, the companies concerned may face penalties of up to $1 \%$ of the total turnover in the proceeding year ${ }^{22}$. Additionally, periodic penalty payments ${ }^{23}$ may be imposed of up to $5 \%$ of the average daily turnover in the preceding business year per day and calculated from the date appointed by the decision (in order to compel them to supply complete and correct information, as requested by the European Commission's decision under Article 18(3) of Regulation 1/2003).

\subsection{Limitations to (scope of) information requests}

Both the TCA and the European Commission are vested with broad powers to request information and determine the periods for the response. The main question that arises here is how to protect the companies/individuals against the disproportionate intervention by the competition authorities, i.e. what the limits to the competition authority's power to request information are. Normally, a measure is disproportionate when it is taken in the absence of facts "capable of justifying the interference with the fundamental rights of an undertaking" 24 and when it constitutes an excessive interference with those rights ${ }^{25}$.

101 TFEU] or any abuse of a dominant position prohibited by [Article 102 TFEU]. When complying with a decision of the Commission, undertakings cannot be forced to admit that they have committed an infringement, but they are in any event obliged to answer factual questions and to provide documents, even if this information may be used to establish against them or against another undertaking the existence of an infringement".

${ }^{20}$ CJ judgment of 19.05.1994, Case C-36/92 P SEP v Commission, ECLI:EU:C:1994:205, para. 21.

21 Article 18(1) of Regulation 1/2003.

22 Article 23 of Regulation1/2003 states that "The Commission may by decision impose on undertakings and associations of undertakings fines not exceeding $1 \%$ of the total turnover in the preceding business year where, intentionally or negligently: (a) they supply incorrect or misleading information in response to a request made pursuant to Article 17 or Article 18(2); (b) in response to a request made by decision adopted pursuant to Article 17 or Article 18(3), they supply incorrect, incomplete or misleading information or do not supply information within the required time-limit..."

23 Article 24 of Regulation 1/2003.

${ }^{24}$ CJ judgment of 22.10.2002, Case C-94/00 RoquetteFrères, ECLI: EU:C:2002:603, para. 55; ECJ judgment of 17.10.1989, Joined cases C-97/87 to 99/87 Dow Chemical Ibérica and Others v Commission, ECLI:EU:C:1989:380, para. 52.

25 C-94/00 Roquette Frères, para. 76 and 80. 
In its recent cement cartel judgements (Case C-247/14 P Heidelberg Cement v Commission ${ }^{26}$, C-248/14 P Schwenk Zement v Commission ${ }^{27}, \mathrm{C}-267 / 14 \mathrm{P}$ Buzzi Unicem v Commission ${ }^{28}$, C-268/14 P Italmobiliare v Commission ${ }^{29}$ ), the Court of Justice (CJ) set aside the 2014 rulings of the General Court (GC) where the GC upheld the statement that it was for the European Commission to decide what information it considered necessary to request in the process of antitrust investigations and deciding whether the infringement took place. The CJ supported the applicants' position and limited powers of the European Commission to request extensive information/documents in its formal requests for information.

These cement cartel judgements arose from the 2011 formal requests for information of the European Commission addressed to several cement companies suspected in participating in the cement cartel. The companies were requested to provide extraordinary quantities and very diverse types of data within a relatively short period of time (a questionnaire itself was 67 pages long, in relation to economic activities of companies in $12 \mathrm{EU}$ member states for a period of more than a decade; financial documents; information that was already publicly available etc.). Moreover, they were asked to provide that data in a very specific and strict format, which involved significant amount of additional work since the parties had to perform numerous, complex and burdensome operation on formatting/re-formatting of that data, which in principle should have been carried out by the European Commission ${ }^{30}$.

Seven companies brought an action before the GC to cancel the European Commission's decision. Following GC's judgement not in their favour, certain companies appealed to the CJ. In March 2016, the CJ delivered its judgement supporting the companies' position and setting aside the GC's judgments by stating that the GC "erred in law in finding that the Commission decisions were adequately reasoned" 31 . Interestingly, by the time of the judgment, the European Commission decided to close its investigation due to the lack of evidence of the existence of the cement cartel. Nevertheless, the judgments

${ }^{26}$ CJ judgment of 10.03.2016, Case C-247/14 P Heidelberg Cement v Commission, ECLI:EU:C:2016:149.

27 CJ judgment of 10.03.2016, Case C-248/14 P Schwenk Zement v Commission, ECLI:EU:C:2016:150

28 CJ judgment of 10.03.2016, Case C-267/14 P Buzzi Unicem v Comission, ECLI:EU:C:2016:151.

${ }^{29}$ CJ judgment of 10.03.2016, C-268/14 P Italmobiliare v Commission, ECLI:EU:C:2016:152.

30 Opinion Of Advocate General Wahl delivered on 15.10.2015, Case C-247/14 P HeidelbergCement AGv European Commission, para. 119, available at http://curia.europa.eu/ juris/document/document.jsf?text $=\&$ docid=169761\&doclang $=$ EN\#Footref76 (3.03.2017).

31 Case C-247/14 P Heidelberg Cement v Commission, para. 40. 
are of great importance for the future of the procedural aspects on the investigatory powers of the competition authorities.

From the judgments, it is clear that the main mistake made by the European Commission was insufficiently explaining the reasons for requesting that information (why such burdensome information was necessary for the investigation). Hence, it is not that the European Commission could not ask for extensive/detailed information, but rather that it cannot do so without providing sufficient reasons (proving necessity) for that.

In assessing the necessity of the request against the level of detail/clarity of the European Commission's statement of reasons, the CoJ relied on the proportionality test (Frenz, 2016, p. 1289) involving two main variables - (1) quantity and complexity of the information requested and, (2) the actual capacity of the parties to provide that information.

"The quantity and complexity of the information requested depends, obviously, on many variables: the seriousness of the suspected infringement, the nature of the involvement of the undertaking concerned, the importance of the evidence sought, the amount and type of useful information which the Commission believes to be in the possession of the undertaking in question"32.

In other words, the European Commission should have indicated the purpose of the request for information with "sufficient precision" 33 in order to determine the necessity of information for the purposes of the investigation.

Consequently, the CJ ruled that the European Commission's statement of reasons was "[...] excessively succinct, vague and generic - and in some respect, ambiguous. Such types of statement of reasons do not fulfil the requirements of the obligation to state reasons as laid down in Article 18(3) of Regulation $1 / 2003^{34}$. In addition, another important conclusion to the benfit of the undertakings subject to investigation is that the Competition Authority should not require "exceptional efforts" from the undertaking. "After all, it is not an undertaking's role to perform the tasks of the Commission, and that holds true irrespective of the size of that undertaking and the means at its disposal" 35 .

As regards to the Turkish Competition Law, it does not contain any specific boundaries to the powers of the TCA regarding its investigation tools and scope of information requests in particular. Nevertheless, the TCA's powers are not limitless. Ratio legis of the Turkish Competition Law shall be regarded as the first boundary to the investigatory powers of the TCA. Correspondingly, the

32 Opinion of Advocate General Wahl, 15.10.2015, Case C-247/14 P Heidelberg Cement $v$ Commission, para. 129.

33 Case C-247/14 P Heidelberg Cement, para. 24.

${ }^{34}$ Case C-247/14 P Heidelberg Cement, para. 39.

35 Opinion Of Advocate General Wahl in Case C-247/14 P Heidelberg Cement, para. 133. 
TCA is obliged to use its investigatory powers in order to ensure compliance with provisions of the TCL, namely Article 4, 6 and 7 thereof. Right to privacy, which is explicitly envisaged by the Constitution of the Republic of Turkey, shall be regarded as the second boundary to the investigatory powers of the TCA. Accordingly, the TCA is not able to expand its investigatory powers to the information, documents and other data, which actually belong to employees of undertakings under investigation and therefore bear a personal character, hence falling under the scope of personal data protection regime. In addition to these two possible limitations to the powers of the TCA to request information, it is anticipated that following the court judgments in cartel cases in the EU, the TCA's discretion in deciding on the scope of information requested and setting the periods for response will be further clarified.

Indeed, the analysed developments in relation to the obligation to state reasons in the information requests are crucial for the undertakings subject to antitrust investigations for the purposes of enabling them to understand the reasons for the particular action so that they can exercise their rights to defence in a proper way. As confirmed by the CoJ, the obligation to state specific reasons is "a fundamental requirement, designed not merely to show that the request for information is justified but also to enable the undertakings concerned to assess the scope of their duty to cooperate whilst at the same time safeguarding their rights of defence" 36 . Hence, the more burdensome the request is, the higher the burden of proof on the competition authority should be why the response to the request is necessary. It is expected that the judgments will have impact on the powers of competition authorities in third countries' jurisdictions which have undertaken certain obligations in terms of harmonizing their legislation with the EU standards, e.g. Turkey.

\section{Most common competition law violations in cement sector: major cases in Turkey}

\section{1997-1999 investigations}

As already mentioned, the TCA has been investigating the cement sector in Turkey since its establishment in 1997 in order to induce a more competitive

36 Case C-247/14 P Heidelberg Cement, para. 19. See also: joined cases $97 / 87$ to $99 / 87$ Dow Chemical Ibérica and Others v Commission, para. 26; C-94/00 Roquette Frères, para. 47; CoJ judgment of 25.06.2014, Case C-37/13 P Nexans and Nexans France v Commission, ECLI:EU:C:2014:2030, para. 34; CoJ judgment of 18.06.2015, Case C-583/13 P Deutsche Bahn and Others $v$ Commission, ECLI:EU:C:2015:404, para. 56. 
environment. Today cement producers are more cautious about their practices and competition law compliance. But the cement market still remains under the scrutiny of the TCA. Price fixing and market sharing have been among the most common competition law violations detected by the TCA in the cement sector. This has been confirmed by the Report findings ${ }^{37}$ and the TCA's decisions, the highlights of which are provided below.

One of the first investigations conducted by the TCA was in relation to 5 companies in the Aegean region ${ }^{38}$ (Dernek, 1998, p. 25) of Turkey. In its Decision No 99-30/276-166(a), dated 17 June 1999, the TCA concluded that the cement manufacturers acted in breach of competition law by way of setting their sales prices and partitioning the market geographically. As a result, the TCA imposed a fine on the companies.

At the very same time, the TCA launched another investigation against 22 companies operating in Central Anatolia, Marmara and Mediterranean regions of Turkey to determine whether they concluded an anti-competitive agreement or/and abused their dominance. The investigation was completed by the Decision No 02-06/51-24 dated 1 February 2002 imposing a fine on 18 companies, which were found acting in violation of competition law by way of price fixing and market sharing.

\section{2003-2004 investigation}

In 2003, the cement companies from the Aegean region (the same as in the 1997 investigation) were again under the scrutiny of the TCA. They were found guilty and fined again for price fixing, with TCA's Decision No 04-77/1108-277 dated 2 December 2004.

It should be mentioned that the above-mentioned decision was appealed to the court (Council of State). The TCA's Decision No 99-30/276-166(a) was appealled to and annulled by the Council of State due to the fact that the text/explanation of the dissenting vote mentioned in the decision was missing. Subsequently the TCA appealed the latter decision of the Council of State, however the TCA's application was rejected and the annulment decision became final. It should be mentioned that in the course of the review of the decision by the Council of State, the TCA in order to avoid the annulment of its decision due to the mentioned procedural deficiency, issued the same decision with the addition of the text of the dissenting vote. Nevertheless, the Council of State annulled the mentioned decision and the TCA subsequently

37 TCA - Cement Sector Report, Section I, p. 5, para. 3.

38 Turkey is traditionally divided into seven geographic/economic regions: Marmara, Aegian, Mediterranean, Black Sea, Central A., Eastern A., and S. Eastern A. 
had to adopt a separate Decision No 05-57/850-230 dated 13 September 2005. This decision was again appealed by four out of five companies to the Council of State and annulled - again on the procedural grounds - for the lack of the majority of the TCA's Board members in the process of taking the decision. Subsequently, the TCA rendered Decision No 07-62/740-268 dated 26 July 2007 and imposed fines on the undertakings.

As regards the TCA's Decision No 02-06/51-24, it was also annulled by the Council of State upon the appeal application of the investigated undertakings. Subsequently, the TCA had rendered its final decision and imposed various fines on investigated undertakings ${ }^{39}$.

The TCA's Decision 04-77/1109-278 dated 2 December 2004 was also set aside by the Council of State due to the participation in the decision taking process of the TCA's Board member, which previously was involved in the investigation process. Afterwards the TCA rendered its final Decision 06-77/992-287 dated 19 October 2006.

Therefore, the 1999, 2002 and 2004 decisions were appealed and set aside by the court on the ground of procedural deficiencies. The decisions were subsequently reassessed by the TCA but without changing substance and hence the amount of fines ${ }^{40}$ for the parties concerned.

\section{2012-2014 investigation}

In April 2012 with its Decision 12-17/499-140, the TCA decided to launch an investigation against 10 cement companies which allegedly violated Article 4 of the TCL. The investigation was launched upon complaint from the Adana Chamber of Commerce and three The TCA decided that investigated undertakings had engaged in price-fixing upon the meeting arranged by marketing executives of the mentioned undertakings and thus infringed Article 4 of the Law No 4054. Following the investigation, the TCA in its Decision No 14-07 /138-M dated 19 February 2014 determined that the mentioned companies were indeed acting in violation of Article 4 TCL and imposed a fine on them.

The TCA's Decision No 14-07/138-M was appealed to and set aside by the court. Later, upon this cancellation, the same applicants requested an investigation again, but this time the investigation was conducted only in

39 TCA's Decision No 06-29/354-86 and dated 24 April 2006.

40 According to Article 17(6)of Law of Turkey No 5326 (Misdemeanor Law) in case the administrative fine is being paid prior to applying for any legal remedies/appeal, the undertaking concerned shall be entitled to a $1 / 4$ discount. Such advance payment is without prejudice to the right to apply for the legal remedy. 
relation to two companies. It was determined that these two companies were severely penalized and the amount of fine was reduced. Six undertakings were fined with an amount corresponding to $2 \%$ of their turnover in financial year 2011 and four undertakings were fined with an amount corresponding to $3 \%$ of their turnover in financial year 2011.

Unlike in the EU, there has not been any precedent of appeal of the TCA's decision on the grounds of extensive information requests yet; although most of the appeals in Turkey are related to the procedural deficiencies and decision-making powers of the TCA.

\section{2014-2016 investigations}

\subsection{No violation found}

In October 2014, the TCA received complaint against cement producers with allegations that the undertakings were involved into price-fixing, shared customers and forced their dealers to behave in accordance with customer allocation. A preliminary report of the experts was prepared on 14 November 2014. Subsequently the TCA's Board initiated a pre-investigation against cement producers, involving on-the-spot inspections and document collection.

Taking into account the characteristics of allegations, specifications of cement and the TCA's precedents, the Board defined the relevant product market as "bagged and bulk grey cement market". The sales activities of the investigated undertakings geographically overlapped in "Balıkesir, Bursa and Yalova”.

The TCA assessed the practices in light of Article 4 of the TCL. Considering the documents obtained within on-the-spot inspections and their assessments, the TCA's Board stated that it could not find sufficient evidence concerning the involvement of investigated undertakings into the anti-competitive agreement. Besides, according to the Board's findings, it was quite possible for such price increases to take place within the period in question without any collusion among competitors. Furthermore, the TCA stated that during the on-the-spot inspections, on the contrary to the allegations of the complainants, it obtained documents indicating customers purchased cement from different producers within the same period. Finally, the TCA by majority vote decided ${ }^{41}$ not to launch an investigation against the undertakings.

Another complaint to the TCA against cement producers was registered on 25 February 2015. According to allegations, the undertakings subject to

41 TCA's Decision of 22.01.2015 No 15-04/51-24. 
investigation increased their prices every other week, allocated customers within the relevant market (defined by the TCA as the "grey cement market"), and one of the undertakings (Votorantim) was the one providing the basis for making aforementioned practices happen. Preliminary report of the experts was prepared on 20 March 2015. Subsequently, on 2 April 2015, the TCA's Board initiated a pre-investigation against cement producers.

In the course of investigation, the TCA did not find anything that could be considered solid evidence revealing the alleged collusion under Article 4 TCL. On the contrary, Board got documents demonstrating the existence of competition within the relevant market. As for the increase in price, the Board stipulated that in order to assert whether the increase in price arises from an agreement between competitors, relevant allegation had to be supported with sufficient evidence, but no such was discovered within the investigation in question. As regards the allocation of customers between investigated cement producers, according to the findings of the TCA's Board, the investigated undertakings always made sales to different customers except one. That said, in the course of on-the-spot inspections, the Board did not obtain any evidence demonstrating such allocation.

Subsequently the Board concluded that there was no information/document showing the existence of either an agreement or a concerted practice, and by the majority vote decided ${ }^{42}$ not to launch an investigation against mentioned undertakings.

These two cases demonstrate that inspite of having a reputation of a "problematic sector", some behaviour of cement producers and developments in the cement market in Turkey may be justified by economic reasons.

\subsection{Allegations confirmed}

The TCA launched its latest investigation against 6 cement producing companies in June 2014 upon complaints received from the Ministry of Customs of Turkey and Trade, Alanya Chamber of Commerce and Industry and Manisa governorship ${ }^{43}$. Interestingly, 4 out of 6 investigated cement producers were the same companies investigated and fined back in 1999 and 2004.

The TCA examined the quantities and price dynamics for the bulk cement in the Aegean region of Turkey, where the cement companies sell their products. In addition to that the TCA conducted inspections at the investigated companies and examined documents in three different periods: January-March 2013 (the cement market was found to be of a competitive structure), between

42 TCA's Decision of 9.07.2015 No 15-29/434-127.

43 Seven of the applicants claimed privacy. 
January-March 2013 and October-December 2014 (documents discovered confirmed communications among the parties, including discussions on the future sales strategies for 2014, information exchanges on the stock amounts, variable costs, etc. In addition to that, according to the minutes of the meeting found, the parties participated in two meetings in order to discuss exportrelated topics), and October-December $2014^{44}$.

Therefore, the TCA found sufficient evidence to conclude that the meetings and information exchanges between the parties were enough to establish a relationship that could influence their market behaviour and result in a similar conduct, thereby preventing/restricting competition in the cement market. The TCA compared this period with the normal market conditions (January 2009-2013) and determined that following January 2013 the average prices increased for approx. 83\% within 21 months (while the unit production cost went up approx. $16 \%$ only). The profit rates of the companies under investigation reflected the price increases significantly over costs increases. Therefore, price increases could not be explained with reasonable economic justifications ${ }^{45}$.

As a result of the investigation, the TCA in its Decision No 16-02/44-14 dated 14.01.2016 the TCA determined that the mentioned cement producing companies between January-March 2013 and October-December 2014 were engaged in anticompetitive concerted practices under Article 4 TCL. In particular, they (i) allocated the markets/customers based on the location of cement plants; (ii) prevented dealers from selling other brands of cement, and increased their prices for more than what would have been necessary under the normal economic conditions and interrelation between the cost/supply and demand. The TCA imposed fines on the companies.

The above described investigations conducted by the TCA over the period of 1999-2016 prove that horizontal price fixing, customer and market allocations (in the ready-mixed concrete market mostly) are among the most common competition law issues detected by the TCA in the cement sector in Turkey. Same companies are often subject to repeteated investigations and fines. This demonstrates that fines do not always serve as an effective deterrence tool for competition law violations.

${ }^{44}$ Competition Bulletin, TCA, No 61m July 2016, External Relations, Training and Competition Advocacy Department (retrieved from: http://www.rekabet.gov.tr/File/?path $=$ ROOT $\% 2 \mathrm{f} 1 \% 2 \mathrm{fDocuments} \% 2 \mathrm{fB} \% \mathrm{C} 3 \%$ BClten $\% 2 \mathrm{fCompetition}+$ Bulletin + No $+61+-$ +July+2016.pdf (25.03.2017).

45 Competition Bulletin, TCA, No 61, July 2016, External Relations, Training and Competition Advocacy Department 


\section{Conclusion}

The cement sector inquiry and the Cement Sector Report outline main substantive issues related to competition in the cement sector in Turkey. Horizontal price fixing, customer and market allocation and abuse of dominant position in the ready-mixed concrete market are among the most common competition law issues detected by the TCA in the cement sector in Turkey.

The Cement Sector Report places particular emphasis on price increases and market partitioning. It concludes that there is no direct correlation between the price increases and economic parameters of the market, i.e. demand, cost of production, season and overall level of efficiency. Irrespective of increased efficiency levels, the prices would not go down. In other words, inspite of efficiency, the producers would continue to apply high prices. There is also no unquestionable relation between the cement prices and seasonal demand. Any price increase defence strategies based on the seasonality of the cement market are unlikely to be accepted by the TCA in the future without any other convincing information/evidence.

The common behavior in the cement sector is 'joint profit maximization', i.e. prices observed in the cement market are above the level that may be expected under the oligopolistic competition normally. However, it does not necessarily confirm the existence of the anticompetitive practices; rather it may be a result of rational choices of the cement companies in the circumstances of an oligopolistic market. As for the market partitioning/allocation, the TCA found that most of the cement used in the rural areas is obtained from the local facilities, i.e. where it is produced. The market shares of the cement producers are rather symmetric throughout Turkey. It may be anticipated that the economic activities of the cement companies in Turkey will continue to be under a special scrutiny of the TCA in order to deal with the current/potential competition problems and improve competition climate in the cement market.

As for the procedural issues, considering the recent cement cartel judgements in the EU limiting the power of the European Commission to request unnecessary burdensome information, it is expected that the respective impact will be felt in Turkey as well. The key issue here is that the more burdensome the request, the higher the burden of proof on the Competition Authority (statement of reasons) should be why the response to the request is necessary. Another important conclusion to the benfit of the undertakings subject to investigation is that the Competition Authority should not require "exceptional efforts" from the undertaking (in other words, it is not the undertaking's role to perform tasks of the competition authority).

Investigations conducted by the TCA over the period of 1999-2016 prove same companies are often subject to repeteated investigations and fines. This 
demonstrates that fines do not always serve as an effective deterrence tool for competition law violations. The TCA decisions are normally appealled to and set aside by the court on the grounds of procedural deficiencies and decision making powers of the TCA. The decisions are being subsequently reassessed by the TCA but without changing substance and hence the amount of fines for the parties concerned. Unlike in the EU, there has not been any precedent of appeal of the TCA's decision on the grounds of extensive information requests yet.

Finally, in spite of having a reputation of a "problematic sector", the behaviour of cement producers and developments in the cement market in Turkey may still be justified by economic reasons and the oligopolistic structure of the market. Even if the undertakings compete with each other, it is not realistic to anticipate price trends that would be present under a fully competitive market structure. Hence, there should be no prejudgments that the cement sector is anticompetitive per se. However, a thorough analysis is required on a case-by-case basis.

\section{Literature}

Çelen, A., Gunalp, B. (2010). Do Investigations of Competition Authorities Really Increase the Degree of Competition? An Answer From Turkish Cement Market. Prague Economic Papers, 19(2), 150-168, https://doi.org/10.18267/j.pep.369

Dernek, I. (1994). Performance analysis of the privatized cement companies. M.A. Thesis. Bogazici University. Institute of Social Sciences. Retrieved from: http://seyhan.library. boun.edu.tr/record =b1154512 $\sim$ S5 (20.01.2017).

Dumez, H. and Jeunemaître, A. (2000). Understanding and Regulating the Market at a Time of Globalization. The Case of the Cement Industry. Macmillan Press: Houndmills, Basingstoke, Hampshire and London, https://doi.org/10.1057/9780230288751.

European Commission (2014). Antitrust: Commission welcomes General Court judgments in cement cartel case confirming its investigatory Powers. Press release. Retrieved from: http://europa.eu/rapid/press-release_MEMO-14-192_en.htm (20.01.2017).

European Commission (2010). Antitrust: Commission opens antitrust proceedings against a number of cement manufacturers. Press release. Retrived from: http://europa.eu/rapid/ press-release_IP-10-1696_en.htm?locale $=$ en (20.01.2017).

Frenz, W. (2016). Handbook of EU Competition Law. Springer-Verlag: Berlin Heidelberg, https://doi.org/10.1007/978-3-662-48593-4.

OECD (2011). Roundtable On Promoting Compliance With Compettion Law - Note by the Delegation of Turkey, Directorate For Financial And Enterprise Affairs Competition Committee. DAF/COMP/WD(2011)36. Retrieved from: http://www.rekabet.gov.tr/File/ ?path=ROOT\%2f1\%2fImages\%2fHaber\%2f71_Compliance_Turkey.pdf (20.01.2017).

Rekabet Kurumu (2016). Çimento Sektör Araştirmasi. Haziran: Ankara. Retrieved from http://www.rekabet.gov.tr/File/?path=ROOT\%2f1\%2fDocuments\%2fG\%C3\%BCnc 
el\%2fraporlar\%2f\%C3\%87imento+Sekt\%C3\%B6r+Raporu+-+Ticari+s\%C4\%B1 rlardan+ar\%C4\%B1nd\%C4\%B1r\%C4\%B1lm\%C4\%B1\%C5\%9F.pdf (27.03.2017).

Whish, R. (2001). New Economy, Old Competition Policy? Paper presented at The Second Annual Conference on the Impact of Globalisation and New Technology on Competition, Competition Commission of South Africa. Lynwood Ridge, South Africa. 